
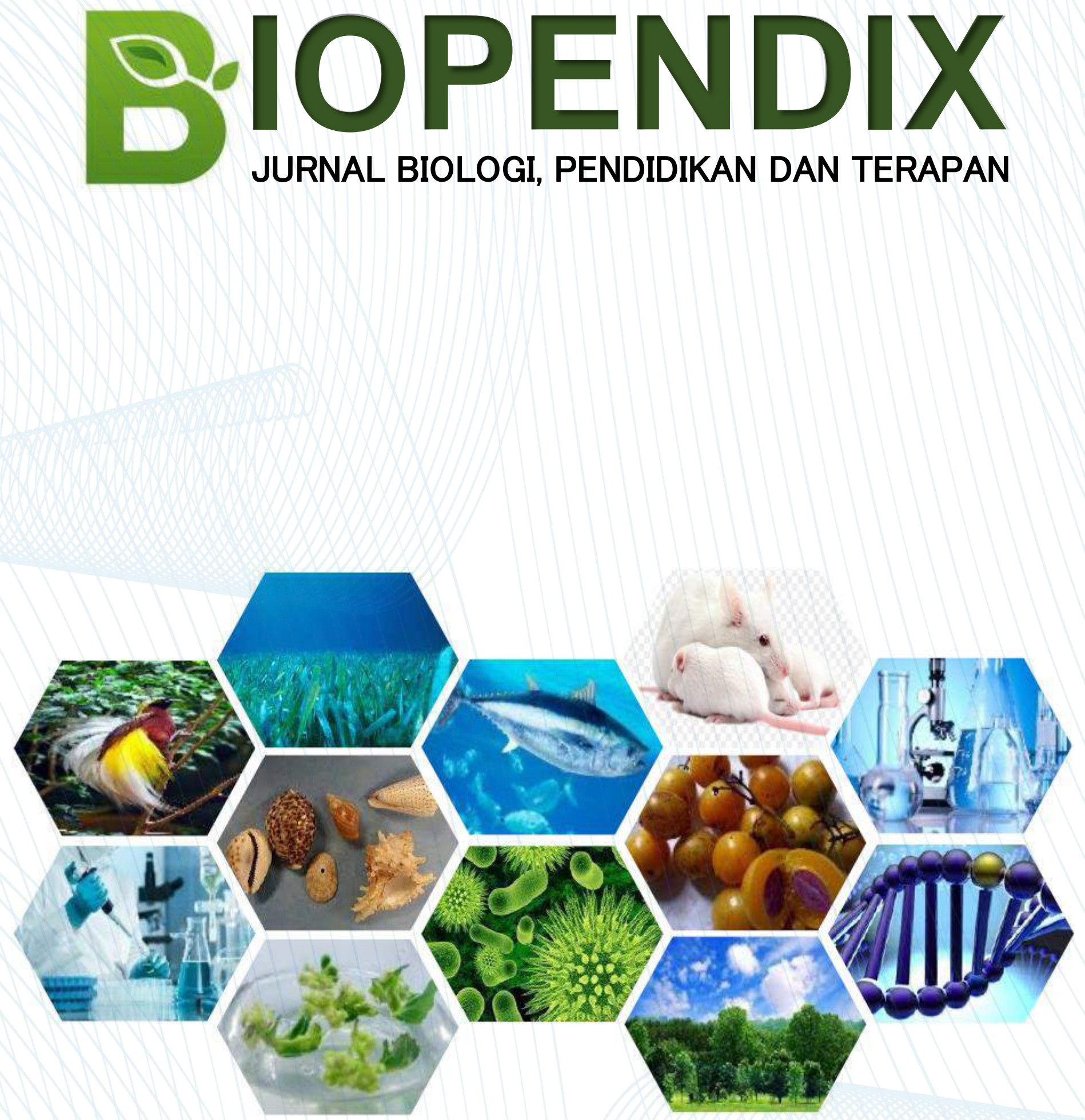

PUBLISHER BY:

BIOLOGY EDUCATION, UNPATTI AMBON - MALUKU 


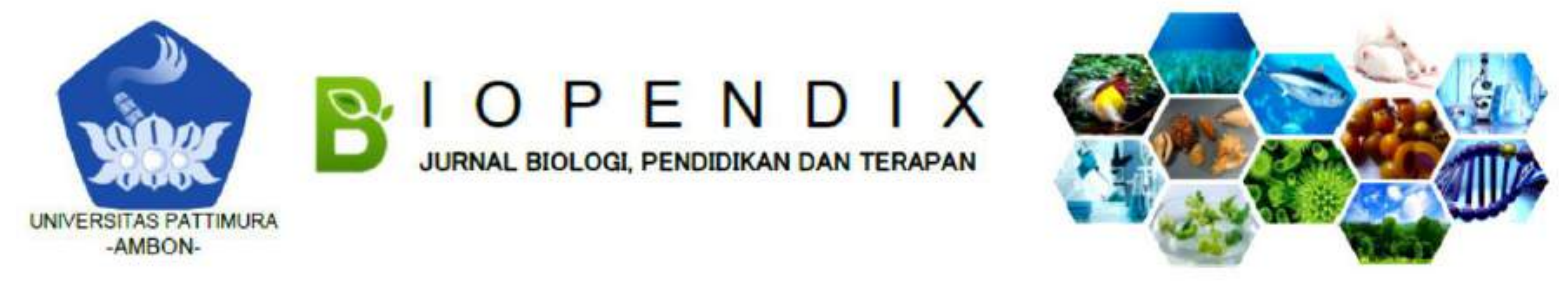

\title{
PENERAPAN MODEL PEMBELAJARAN KOOPERATIF TIPE TWO STAY TWO STRAY DIPADUKAN DENGAN TIPE MAKE A MATCH UNTUK MENINGKATKAN HASIL BELAJAR BIOLOGI PADA SISWA KELAS VIII SMP NEGERI 2 AMBON MATERI ZAT ADITIF DAN ZAT ADIKTIF
}

\author{
Hartia $^{1}$, F. Leiwakabessy ${ }^{2}$, Ine Arini ${ }^{\star 2}$ \\ ${ }^{1}$ Alumni Program Studi Pendidikan Biologi \\ ${ }^{2}$ Program Studi Pendidikan Biologi
}

\section{Corresponding Author: Ine Arini; e-mail: iairini.unpatti@gmail.com}

\begin{abstract}
Background: The Two Stay Two Stray cooperative learning model is one of the cooperative learning techniques that provides opportunities for groups to discuss sharing results and information with other groups. The Make a Match model is part of cooperative learning in which the learning model the teacher prepares a card that contains problems or problems and prepares an answer card then the student looks for the pair of cards. This study aims to determine the improvement of Biology learning outcomes for VIII grade students of SMP Negeri 2 Ambon on additive material and taught using the Two Stay Two Stray cooperative learning model combined with the Make a Match type.

Method: This research was conducted from 10 October to 7 November 2019. The type of research used was descriptive. The research subjects were students of class VIII bill 1, totaling 23 students. The instruments used were preliminary and final tests, observation sheets, worksheets.

Results: The results showed that there was an increase in student learning outcomes from $39.52 \%$ to $100 \%$. After being taught with the Two Stay Two Stray cooperative learning model combined with the Make a Match type.

Conclusion: There is an increase from the initial test results of students who have not reached the minimum completeness criteria and the final test has reached the Minimum completeness Criteria (KKM).
\end{abstract}

Keywords: Two Stay Two Stray, Make A Match, Learning Outcomes

\begin{abstract}
Abstrak
Latar Belakang: Model pembelajaran kooperatif tipe Two Stay Two Stray yaitu salah satu teknik pembelajaran kooperatif yang memberikan kesempatan kepada kelompok untuk berdiskusi membagikan hasil dan informasi kepada kelompok lain. Model Make a Match adalah bagian dari pembelajaran kooperatif yang di dalam model pembelajaran ini guru menyiapkan kartu yang berisi soal atau permasalahan dan menyiapkan kartu jawaban kemudian siswa mencari pasangan kartunya. Penelitian ini bertujuan untuk mengetahui peningkatan hasil belajar Biologi pada siswa kelas VIII SMP Negeri 2 Ambon pada materi zat aditif dan diajarkan dengan menggunakan model pembelajaran kooperatif tipe Two Stay Two Stray dipadukan dengan tipe Make a Match.

Metode: Penelitian ini dilaksanakan dari tanggal 10 Oktober - 7 November 2019. Tipe penelitian yang digunakan adalah deskriptif. Subjek penelitian adalah siswa kelas VIII bill 1 yang berjumlah 23 siswa. Instrumen yang digunakan adalah tes awal dan tes akhir, lembar observasi, LKS. Hasil: Hasil penelitian menunjukan bahwa ada peningkatan hasil belajar siswa dari hasil tes $39,52 \%$ menjadi $100 \%$. Sesudah diajarkan dengan model pembelajaran kooperatif tipe Two Stay Two Stray dipadukan dengan tipe Make a Match.

Kesimpulan: Ada peningkatan dari hasil tes awal siswa yang belum mencapai kriteria ketuntasan minimal dan tes akhir telah mencapai Kriteria Ketuntasan Minimal (KKM).
\end{abstract}

Kata Kunci: Two Stay Two Stray, Make A Match, Hasil Belajar 


\section{PENDAHULUAN}

Pendidikan menjadi salah satu modal penting untuk memajukan sebuah bangsa karena kesejahteraan dan kemajuan sebuah bangsa dapat dilihat dari tingkat pendidikannya. Pendidikan juga dipandang sebagai sarana untuk melahirkan insaninsan yang cerdas, kreatif, terampil, bertanggung jawab, produktif, dan berbudi pekerti luhur (Hartoto, 2016). Belajar merupakan kegiatan aktif siswa dalam membangun makna atau pemahaman terhadap suatu konsep, sehingga dalam proses pembelajaran siswa merupakan sentral kegiatan, dari perlakuan utama. Guru menciptakan suasana yang dapat mendorong timbulnya motivasi belajar siswa (Wahyuni dkk, 2014). Pelajaran Biologi merupakan pelajaran yang menarik dan menyenangkan serta berkaitan dengan kehidupan sehari-hari, agar pembelajaran Biologi dapat terlaksana dengan baik dan tercapainya tujuan pembelajaran yang maksimal maka siswa harus dapat memahami konsep-konsep materi yang diberikan guru pada saat proses pembelajaran (Kurniawan, 2013).

Berdasarkan hasil observasi yang telah dilakukan dengan guru mata pelajaran Biologi SMP Negeri 2 Ambon, proses pembelajaran Biologi masih berfokus kepada guru sebagai informator yang berperan dominan dalam setiap proses pembelajaran. Hasil wawancara dengan guru Biologi menyatakan bahwa keterampilan sosial siswa masih rendah. Hal ini terlihat pada saat guru memberikan masalah dan harus dipecahkan dengan berdiskusi, siswa lebih memilih untuk memecahkan masalah tersebut sendiri, siswa lebih bersikap individual dalam menyelasaikan tugasnya. Kegiatan diskusi biasanya masih didominasi oleh siswa tertentu yang lebih aktif dalam anggota kelompok. Berdasarkan hal tersebut maka perlu dilakukan usaha untuk meningkatkan keterampilan sosial siswa melalui pembelajaran Biologi dengan menerapkan suatu model pembelajaran yang dapat mengaktifkan siswa untuk saling bertukar pikiran dan saling menunjang dalam proses pembelajaran.

Penerapan model pembelajaran yang bervariasi mengatasi kejenuhan siswa sehingga dapat dikatakan bahwa model pembelajaran sangat berpengaruh terhadap tingkat pemahaman siswa (Surianto dkk, 2014). Model pembelajaran kooperatif tipe Two Stay Two Stray yaitu salah satu teknik pembelajaran kooperatif yang memberikan kesempatan kepada kelompok untuk bediskusi membagikan hasil dan informasi kepada kelompok lain. Model pembelajaran ini terdiri dari beberapa kelompok yang tiap kelompoknya terdiri dari 4 siswa. Dalam model pembelajaran ini ada kegiatan bertamu dan menerima tamu untuk membagikan hasil informasi setelah mereka berdiskusi dengan teman sekelompoknya. Melalui model pembelajaran ini diharapkan mampu merangsang partisipasi siswa untuk lebih aktif dalam berdiskusi, mengeluarkan pendapatnya sesuai dengan kemampuan mereka masing-masing sehingga suasana kelas menjadi kondusif dan dapat meningkatkan hasil belajar (Arumsari dkk, 2015).

Menurut Suyatno dalam Ningtyas dkk, (2017) mengungkapkan bahwa model Make a Match adalah bagian dari pembelajaran kooperatif yang di dalam model pembelajaran ini guru menyiapkan kartu yang berisi soal atau permasalahan dan menyiapkan kartu jawaban kemudian siswa mencari pasangan kartunya dimana melakukan model pembelajaran ini diperlukan keaktifan siswa dalam kemampuan berfikir. Hasil belajar adalah ukuran tingkat keberhasilan yang dapat dicapai oleh seorang siswa berdasar pengalaman yang diperoleh setalah dilakukan evaluasi berupa tes dan biasanya diwujudkan dengan nilai tertentu serta menyebabkan terjadinya perubahan kognitif, afektif, maupun psikomotorik (Harisandy, 2015).

\section{METODE}

Penelitian ini merupakan penelitian deskriptif yang bertujuan untuk mengetahui penerapan model pembelajaran kooperatif tipe Two Stay Two Stray dipadukan dengan tipe Make a Match dalam peningkatan hasil belajar pada materi zat aditif dan zat adiktif. Penelitian ini dilaksanakan di SMP Negeri 2 Ambon dari tanggal 10 Oktober-7 November 2019.

Populasi yang digunakan dalam penelitian ini yaitu seluruh siswa SMP Negeri 
2 Ambon. Sampel yang digunakan dalam penelitian ini siswa kelas VIII-Bill 1 dengan jumlah siswa 23 orang pengambilan sampel dilakukan teknik purposive sampling. Variabel yang digunakan dalam penelitian ini adalah variabel bebas yaitu pembelajaran dengan menggunakan penerapan model pembelajaran Two Stay Two Stray yang dipadukan dengan model pembelajaran Make a Match dan variabel terikat adalah hasil belajar.

\section{Prosedur Penelitian}

1. Guru menyampaikan salam dan berdoa bersama sebelum memulai kegiatan pembelajaran.

2. Guru mengecek kehadiran siswa.

3. Guru menggali pengetahuan awal siswa tenggang materi yang akan dipelajari (apersepsi).

4. Guru menyampaikan indikator pembelajaran, mengenal dan menjelaskan materi sesuai dengan rencana pembelajran yang telah dibuat.

5. Guru lembar tes awal.

6. Guru membagi siswa dalam beberapa kelompok secara heterogen.

7. Guru membagi LKS serta materi yang akan dibahas dalam kelompok.

8. Guru membuat potongan-potongan kertas sejumlah peserta didik yang ada didalam kelas, menulis pertanyaan tentang materi yang telah diberikan pada setengah bagian kertas berisi satu pertanyaan dan pada separuh kertas lain menulis jawaban.

9. Guru menyuruh 2 siswa dari masingmasing kelompok untuk bertamu kekelompok lain dan siswa yang tinggal bertugas memberi informasi kepada tamu tentang materi yang dibahas dalam kelompok. Setelah itu siswa kembali kekelompok dan menyampaikan informasi yang telah didapat dari kelompok lain.

10. Guru meminta perwakilan kelompok untuk maju mempresentasikan hasil diskusi.

11. Guru membahas dan mengarahkan kebentuk formal.

12. Guru meminta siswa mengambil potongan kertas yang sudah dikocok sebelumnya.
13. Guru meminta siswa mencari pasangan yang mempunyai potongan kertas yang cocok dengannya.

14. Guru membimbing siswa untuk menemukan pasangan dan duduk berdekatan, minta siswa setiap pasangan bergantian untuk membacakan soal yang diperoleh.

15. Guru memberikan lembar soal tes akhir.

16. Guru memberikan evaluasi.

17. Guru meminta salah satu siswa maju kedepan untuk memimpin doa menutup kegiatan pembelajaran.

Data dalam penelitian ini diperoleh melalui tes awal, tes akhir, dan lembar observasi untuk mengetahui kemampuan afektif, dan psikomotor. Data kognitif diperoleh melalui Tes dan LKS. Data kemudian dianalisis menggunakan analisis deskriptif.

1. Hasil belajar (aspek kognitif, afektif, psikomotor)

$$
\text { Skor Pencapaian }=\frac{\text { Jumlah Skor Perolehan }}{\text { Jumlah Skor Maksimal }} \times
$$

2. Untuk mengukur nilai proses.

$$
\mathrm{NP}=\frac{\text { Nilai Kognitif }+ \text { Nilai Afektif }+ \text { Nilai Psikomotor }}{3}
$$

3. $\mathrm{NA}=\frac{6 P+4 F}{10}$

Keterangan: NA: Nilai Akhir, P: Nilai Proses, F: Nilai hasil tes formatif setelah proses pembelajaran.

Setiap siswa dikatakan telah tuntas belajar (kompeten) pada materi ini jika nilai akhirnya telah memenuhi KKM yakni 70, dan untuk kualifikasi ketuntasan siswa, setiap nilai akhir siswa dikonsultasikan dengan mengacu pada Tabel 1.

Tabel 1. Interval Skor pencapaian
Kompetensi.

\begin{tabular}{cc}
\hline Interval skor pencapaian & Kualifikasi \\
\hline$\geq 70$ & Tuntas \\
\hline$\leq 70$ & Gagal \\
\hline
\end{tabular}

Keterangan: 1) Jika siswa memiliki nilai $\geq 70$ dapat dikategorikan berhasil (tuntas) pada aspek kogintif, afektif dan 
psikomotor. 2) Jika siswa memiliki nilai $\leq 70$ dapat dikategorikan tidak berhasil (tidak tuntas) pada aspek kognitif, afektif dan psikomotor.

HASIL DAN PEMBAHASAN

\section{Tes awal}

Hasil penelitian kemapuan tes awal siswa sebelum mengikuti kegiatan belajar mengajar dengan menggunakan Model Pembelajaran Kooperatif Tipe Two Stay Two Stray dipadukan dengan Tipe Make a Match terlihat pada Tabel 2.

Tabel 2. Kualifikasi Hasil Tes Awal

\begin{tabular}{cccc}
\hline Interval & Frekuensi & Persentase & Kualifikasi \\
\hline $85-100$ & - & - & Sangat baik \\
$78-84$ & - & - & baik \\
$70-77$ & - & - & cukup \\
$60-69$ & 2 & 8,70 & Kurang \\
$\leq 59$ & 21 & 91,30 & Gagal \\
Jumlah & 23 & $100 \%$ & - \\
\hline
\end{tabular}

Tingkat kemapuan hasil tes awal siswa sebelum mengikuti proses pembelajaran dengan menerapkan model pembelajran kooperatif tipe Two Stay Two Stray dipadukan dengan tipe Make a Match meunjukan bahwa tes awal siswa tergolong rendah dimana 2 siswa dengan presetase $8,70 \%$ berada pada kualifikasi kurang dan 21 siswa dengan presentase $91,30 \%$ berada pada kualifikasi gagal.

Hasil rata-rata tes awal yang dicapai siswa tidak memenuhi (KKM) yaitu sebesar 39,52 dari yang ditetapkan yaitu 70. Hal ini disebabkan karena guru belum memberikan materi sehingga siswa menjawab tes sesuai dengan pemahaman dan keampuan berfikirnya masing-masing. Sehingga tingkat penguasaan siswa berada pada kualifikasi gagal dikarenakan siswa belum memahami materi tersebut. Tes awal juga digunakan sebagai pembanding apakah ada peningkatan hasil belajar sebelum dan sesudah menerima materi.

\section{Hasil Penilaian Aspek Kognitif}

Penilaian dalam hal ini siswa mengerjakan lembar kerja siswa (LKS) yang digunakan untuk melihat hasil kerja siswa dikelas. Hasil dapat dilihat pada Tabel 3.

Tabel 3. Klasifikasi Penilaian Rata-rata Hasil Aspek Kognitif (LKS)

\begin{tabular}{cccc}
\hline Interval & Frekuensi & Persentase & Kualifikasi \\
\hline $85-100$ & 23 & $100 \%$ & Sangat Baik \\
$78-84$ & & & Baik \\
$70-77$ & & & Cukup \\
$60-69$ & & & Kurang \\
$\leq 59$ & & Gagal \\
Jumlah & 23 & $100 \%$ & \\
\hline
\end{tabular}

Berdasarkan hasil penilaian LKS yang di gunakan untuk menilai hasil kerja siswa terdapat 23 siswa dengan interval 85-100 dengan presentase (100\%) berada pada kualifikasi sangat baik. Hal ini terlihat dari hasil belajar siswa dengan nilai rata-rata $94,75 \%$ dari KKM yang ditentukan. Hasil belajar siswa meningkat karena pada pembelajaran ini siswa diarahkan untuk membentuk kelompok diskusi sehingga siswa lebih mudah memahami konsep materi pembelajaran serta terjadinya interaksi antara teman yang satu dengan yang lainnya.

\section{Hasil Penelitian Aspek Afektif}

Penilaian aspek afektif diperoleh melalui lembar observasi yang digunakan untuk menilai kemampuan siswa yang meliputi: minat dan keseriusan, kerja sama dalam kelompok, kesopanan, dan menjaga ketertiban. Hasilnya pada tabel berikut. 
Tabel 4. Klasifikasi Persentase Hasil Aspek Afektif

\begin{tabular}{cccc}
\hline Interval & Frekuensi & Persentase & Kualifikasi \\
\hline $85-100$ & 16 & 69,56 & Sangat Baik \\
$78-84$ & 7 & 30,43 & Baik \\
$70-77$ & & & Cukup \\
$60-69$ & & & Kurang \\
$\leq 59$ & & & Gagal \\
Jumlah & 23 & $100 \%$ & \\
\hline
\end{tabular}

Berdasarkan tabel 4 terlihat bahwa sebanyak 16 siswa dengan persentase $(69,56 \%)$ memperoleh nilai interval (85-100) dengan keterangan sangat baik, 7 siswa dengan persentase $(30,43 \%)$ memperoleh nilai interval (78-84) dengan keterangan baik.

Ciri-ciri hasil belajar afektif tampak pada siswa dalam berbagai tingkah laku seperti: perhatian terhadap mata pelajaran, kedisiplinan dalam mengikuti proses belajar, motivasi dalam belajar, penghargaan atau rasa hormat terhadap guru dan sebagainya (Sudijono, 2006).

Berdasarkan hasil penelitian yang dilakukan dengan menerapkan model pembelajaran kooperatif tipe Two Stay Two Stray dipadukan dengan tipe Make a Match pada aspek afektif tergolong dalam kualifikasi baik dan sangat baik. Dapat dilihat dari hasil nilai rata-rata yang diperoleh siswa yaitu, $91,55 \%$ dimana 7 siswa berada pada kualifikasi baik dan 16 siswa berada pada kualifikasi sangat baik. Pencapaian kualifikasi ini membuktikan bahwa siswa mampu merespon dengan baik pembelajaran yang berlangsung. Hal ini ditunjukan dengan minat keseriusan, kerjasama dalam kelompok, kesopanan dan menjaga ketertiban.

\section{Hasil Penilaian Aspek Psikomotor}

Berdasarkan data hasil penilaian aspek psikomotor dengan menggunakan penilain proses belajar mengajar yang dinilai berdasarkan empat indikator yaitu kemampuan mendefinisikan, mendeskripsikan, mengidentifikasi, dan menyebutkan. Hasil dari aspek ini dapat dilihat pada Tabel 5.

Tabel 5. Klasifikasi Presentase Hasil Aspek Psikomotor

\begin{tabular}{cccc}
\hline Interval & Frekuensi & Persentase & Kualifikasi \\
\hline $85-100$ & 19 & 82,60 & Sangat Baik \\
$78-84$ & 4 & 17,39 & Baik \\
$70-77$ & & & Cukup \\
$60-69$ & & & Kurang \\
$\leq 59$ & & & Gagal \\
Jumlah & 23 & $100 \%$ & \\
\hline
\end{tabular}

Pada aspek psikomotor 4 siswa dengan persentase $17,39 \%$ memperoleh nilai dengan interval (78-84) dengan kualifikasi baik dan 19 siswa dengan persentase $82,60 \%$ memperoleh nilai interval (85-100) dengan kualifikasi sangat baik, sehingga diperoleh nilai rata-rata 92,02\%. Pencapaian nilai KKM yang ditentukan ini membuktikan adanya peningkatan penguasaan konsep siswa. Aspek psikomotor yang dinilai yaitu peningkatan penguasaan konsep biologi siswa terlihat dalam proses pembelajaran ketika ketrampilan siswa mampu dalam mendefinisikan, mengidentifikasi, dan menyebutkan macammacam zat aditif dan zat adiktif dengan baik. Penilaian hasil belajar yang sifatnya psikomotor dapat dilakukan secara langsung melalui observasi terhadap siswa yang memperlihatkan keterampilan-keterampilan sebagai hasil proses belajar (Rehena, 2009).

\section{Hasil Tes Formatif (Tes Akhir)}

Hasil tes formatif dilakukan setelah siswa selesai proses kegiatan belajar mengajar (KBM) berlangsung dengan materi zat aditif dan zat adiktif. Hasil tersebut dapat dilihat pada tabel 6 . 
Tabel 6. Kualifikasi Persentase Hasil Tes Formatif (Tes Akhir)

\begin{tabular}{cccc}
\hline Interval & Frekuensi & Persentase & Kualifikasi \\
\hline $85-100$ & 11 & 47,82 & Sangat Baik \\
$78-84$ & 8 & 34,78 & Baik \\
$70-77$ & 4 & 17,39 & Cukup \\
$60-69$ & & & Kurang \\
$\leq 59$ & & & Gagal \\
Jumlah & 23 & $100 \%$ & \\
\hline
\end{tabular}

Setelah proses belajar mengajar dengan menerapkan model pembelajaran kooperatif tipe Two Stay Two Stray dipadukan dengan Make a Match siswa diberikan tes berupa tes formatif. Menurut Djaali, 2006, penilaian formatif pada dasarnya adalah penilaian yang dilakukan untuk mendapatkan umpan balik bagi usaha perbaiakan kualitas pembelajaran dalam konteks kelas. Fungsi penilaian formatif adalah membantu untuk mengarahkan atau memonitor perkembangan pembelajaran siswa ketika proses pembelajaran berlangsung (Nurjannah, 2017).

Berdasarkan Tabel 6 terlihat bahwa sebanyak 11 siswa dengan persentase $(47,82 \%)$ mampu menguasai indikator pembelajaran dengan nilai interval (85-100) kualifikasi sangat baik, 8 siswa dengan persentase $(34,78 \%)$ memperoleh nilai interval (78-84) kualifikasi baik, 4 siswa dengan persentase $(17,39 \%)$ memperoleh nilai interval (70-77) dengan kualifikasi cukup. Jika dibandingkan antara nilai KKM dengan rata-rata skor pencapaian siswa pada tes formatif, maka dapat dikatakan pencapaian kemampuan siswa berada pada kategori tuntas dengan rata-rata skor pencapian pada tes formatif adalah 84,08 dari KKM yang ditetapkan yaitu 70 . Hal ini membuktikan bahwa setelah proses belajar mengajar dengan penerapan model pembelajran kooperatif tipe Two Stay Two Stray dipadukan dengan tipe Make a Match, penguasaan materi Biologi pada siswa tentang zat aditif dan zat adiktif menjadi lebih baik dan mencapai kualifikasi kemampuan akhir siswa (Tes Formatif) menggambarkan 23 siswa (100\%) berhasil mencapai nilai KKM.

\section{Nilai Akhir}

Nilai akhir siswa merupakan hasil belajar siswa yang dapat diketahui dari presentase tingkat kemampuan atau penguasaan siswa pada nilai proses dari aspek kognitif, afektif, psikomotor, dan presentase kemampuan atau penguasaan siswa pada hasil tes (tes formatif). Tingkat kemampuan siswa berbeda-beda, dapat terlihat dari hasil nilai akhir. Data kualifikasi nilai akhir (NA) dapat dilihat pada Tabel 7.

Tabel 7. Klasifikasi Presentase Nilai Akhir

\begin{tabular}{cccc}
\hline Interval & Frekuensi & $\mathbf{1 0 \%}$ & Kualifikasi \\
\hline $85-100$ & 20 & 86,95 & Sangat Baik \\
$78-84$ & 3 & 13,04 & Baik \\
$70-77$ & & & Cukup \\
$60-69$ & & & Kurang \\
$\leq 59$ & & & Gagal \\
Jumlah & 23 & $100 \%$ & \\
\hline
\end{tabular}

Hasilnya terdapat 20 siswa dengan persentase $86,95 \%$ memperoleh nilai interval (85-100) dengan keterangan sangat baik, 3 siswa dengan persentase 13,04\% memperoleh nilai interval (78-84) dengan keterangan baik.

Kualifikasi nilai akhir peserta didik juga menggambarkan 23 siswa (100\%) berhasil mencapai nilai KKM yang ditetapkan yaitu 70 , hal ini menunjukan bahwa seluruh siswa mampu menguasai materi yang diajarkan selama proses pembelajaran.

Sehingga dapat disimpulkan penerapan model pembelajaran kooperatif tipe Two Stay Two Stray dipadukan dengan tipe Make a Match dapat meningkatkan hasil belajar 
dimana kedua model pembelajaran ini dapat membuat proses belajar mengajar lebih menyenangkan, siswa dapat belejar sambil bermain sehingga siswa tidak jenuh dalam menerima materi.

Model pembelajaran ini juga membuat semua siswa berperan aktif dalam kelompoknya dan siswa dituntut untuk berdiskusi, mencari jawaban, menjelaskan menyimak dan juga mendengarkan informasi yang disampaikan sehingga dapat meningkatkan kemampuan berfikir siswa dan dapat pula meningkatkan hasil belajar siswa. Hal tersebut sesuai dengan pendapat dari Wardhani dkk (2012) yang menyatakan bahwa pembelajaran yang dilakukan dengan model pembelajaran Two Stay Two Stray (TSTS) dapat meningkatkan keaktifan siswa dalam proses pembelajaran dan pemahaman siswa terhadap materi pelajaran sehingga dapat meningkatkan hasil belajar.

\section{SIMPULAN}

Berdasarkan hasil penelitian dengan menggunakan model pembelajaran kooperatif Tipe Two Stay Two Stray dipadukan dengan Tipe Make a Match dapat meningkatkan hasil belajar siswa kelas VIII SMP Negeri 2 Ambon pada materi zat aditif dan zat adiktif. Hal ini dapat dilihat dari tes awal siswa sebelum proses belajar mengajar tidak mencapai KKM dengan rata-rata tes awal 39,52, setelah menerapkan model pembelajaran kooperatif Tipe Two Stay Two Stray dipadukan dengan Tipe Make a Match adanya peningkatan dimana siswa mencapai nilai KKM ini dibuktikan pada nilai akhir dengan perolehan nilai rata-rata mencapai 89,24 dari nilai KKM yang ditetapkan yaitu 70 .

\section{DAFTAR PUSTAKA}

Arumsari, M. P., Indriayu, M., \& Totalia, S. A. 2015. Penerapan Kombinasi Model Pembelajaran Kooperatif Two Stay Two Stray Dengan Make A Match Untuk Meningkatkan Hasil Belajar Ekonomi Siswa Kelas Xi-lis 6 SMA Negeri 8 Surakarta Tahun Pelajaran 2015/2016. Jurnal Pendidikan Ekonomi, FKIP Universitas Sebelas Maret Surakarta, 57126, Indonesia.
Djaali. 2006. Psikologi Pendidikan. Jakarta: Bumi Aksara.

Harisandy, R. 2015. Peningkatan Hasil Belajar Siswa Kelas XI Pada Mata Pelajaran Pengendali Daya Tegangan Rendah Smk 1 Sedayu Melalui Model Kooperatif Tipe Gi (Group Investigation). Skripsi. Program Studi Pendidikan Teknik Elektro Fakultas Teknik Universitas Negeri Yogyakarta.

Hartoto, T. 2006. Model Pembelajaran Kooperatif Tipe Group Investigation (Gi) Meningkatkan Aktivitas Dan Hasil Belajar Sejarah. Jurnal Historia Volume 4, Nomor 2, Tahun 2016, ISSN 23374713 (E-Issn 2442-8728).

Kurniawan, A. D. 2013 Metode Inkuiri Terbimbing Dalam Pembuatan Media Pembelajaran Biologi Untuk Meningkatkan Pemahaman Konsep Dan Kreatifitas Siswa SMP. Jurnal Pendidikan IPA Indonesia

Ningtyas, E. S. \& Wuryani, E. 2017. Penerapan Model Pembelajaran Kooperatif (Cooperative Learning) Tipe Make-A Match Berbantuan Media Komik Interaktif Untuk Meningkatkan Aktivitas Belajar Dan Hasil Belajar Ips. Jurnal Pendidikan Surya Edukasi (Jpse), Volume: 3, Nomor: 1, Juni 2017

Nurjannah. 2017. Efektivitas Bentuk Penilaian Formatif Disesuaikan Dengan Media Pembelajaran. Jurnal Parameter Volume 29 No. 1

Rehena, J. F. \& Casmudi. 2009. Strategi Pembelajaran. Malang: Universitas Negeri Malang.

Sudijono, A. 2006. Pengantar Statistik Pendidikan. Jakarta: PT.Raja Grafindo Persada.

Surianto, A. M. \& Nurkamto, J. 2014. Penerapan Model Pembelajaran Dengan Metode Two Stay Two Stray (TS-TS) Pada Mata Diklat Teknik Mesin Di Smk Muhammadiyah Sumowono. Jurnal Teknologi Pendidikan Dan Pembelajaran Vol.2 No.2. Hal 199-210.

Wahyuni, A., Gardjito. \& Hariyadi, B. 2014. Analisis Kemampuan Berpikir Kritis Siswa Dalam Aktivitas Belajar Biologi Di Kelas XI IPA Sma Negeri 11 Kota Jambi. FKIP Universitas Jambi. Jurnal Program Studi Pendidikan Biologi, FKIP Universitas Jambi. 
Biopendix, Volume 6, Nomor 2, Pebruari 2020, hlm. 82-90

Wardhani, I.Y., Sajidan, Maridi. 2012. Yariyani, L. 2016. Pengaruh Metode Penerapan Model Pembelajaran Kooperatif Tipe Two Stay Two Stray disertai Media Audio Visual untuk Meningkatkan Kualitas Pembelajaran Biologi Siswa Kelas XI IPA 5 SMA Negeri 7 Surakarta Tahun Pelajaran 2011/2012. Jurnal Pendidikan Biologi. 4 (1): $40-55$ Pembelajaran Make a Match (Mencari Pasangan) Dan Metode Role Playing Terhadap Hasil Belajar IPA Biologi SMP. Skripsi. Program Studi Pendidikan Biologi Pada Fakultas Keguruan Dan IImu Pendidikan Universitas Muhammadiyah Surakarta. 